\title{
Protective Effect of Captopril and Nigella Sativa Oil against Carbon Tetrachloride Induced Nephrotoxicity in Male Rats
}

\author{
Khaled M. Abdel Aal1 and Nashwa A.M. Mostafa2 \\ ${ }^{1}$ Departments of Forensic Medicine \& Clinical Toxicology \\ ${ }^{2}$ Departments of Histology
}

Faculty of Medicine, Assiut University, Assiut, Egypt

\begin{abstract}
Carbon tetrachloride $\left(\mathrm{CCl}_{4}\right)$ is considered an environmental pollutant. Exposure to $\mathrm{CCl}_{4}$ is commonly associated with nephrotoxicity. Objective: The aim of this study was to demonstrate the possible preventive role and underlying mechanism of the single and combined administration of captopril and nigella sativa oil against $\mathrm{CCl}_{4}$ induced nephrotoxicty in male rats. Methods: This study was conducted on sixty four adult healthy male albino rats and divided into 8 groups (8 rats/group). Group I, rats which served as negative control, group II, rats which given liquid paraffin and saline (positive control), groups III, rats which given captopril in a dose of $100 \mathrm{mg} / \mathrm{kg}$ daily by gavage (positive control), group IV, rats which given nigella sativa oil in a dose of $4 \mathrm{ml} / \mathrm{kg}$ daily by gavage (positive control), group V, rats which injected i.p. with $\mathrm{CCl}_{4}$ three times/ week in a dose of $20 \mu \mathrm{L} / 100 \mathrm{gm}$ body weight, group VI, rats which given captopril concurrently with $\mathrm{CCl}_{4}$ in the same mentioned dose and route, group VII, rats which given nigella sativa oil concurrently with $\mathrm{CCl}_{4}$ in the same mentioned dose and route; group VIII, rats which given captopril and nigella sativa oil daily concurrently with $\mathrm{CCl}_{4}$ in the same mentioned dose and route. All rats were given treatment for 6 weeks then sacrificed by decapitation. Biochemical parameters were assessed in all rat groups and statistically analyzed. In addition, histological and immunohistochemical investigations of renal tissues were done. Results: In $\mathrm{CCl}_{4}$ treated rats, the biochemical assays revealed significant statistical increase in the level of serum urea, creatinine, uric acid and nitric oxide as well as increase level of lipid peroxides, reduced glutathione and superoxide dimutase in the kidney tissue. Histological examination showed degeneration of glomeruli and tubules. High immunolabelling for activated caspase-3 in the kidney was detected on immunohistochemical examination. Treatment with captopril and nigella oil singly or in combination with $\mathrm{CCl}_{4}$ resulted in improvement of the biochemical, histological and immunohistological changes and this effect is more evident on their combined administration. Conclusion: Captopril and nigella sativa oil can be used as therapeutic agents in protection against $\mathrm{CCl}_{4}$ induced nephrotoxicity. This effect is attributed to decrease free radicals generation and apoptosis through inhibition of casapse-3 activity in renal tissue. It is recommended to conduct further experimental studies on large numbers and to investigate this effect on nephrotoxic patients.
\end{abstract}

Keywords $\quad \mathrm{CCl}_{4}$, oxidative stress, captopril, nigella sativa oil and kidney.

\section{Introduction}

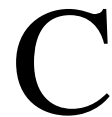
arbon tetrachloride $\left(\mathrm{CCl}_{4}\right)$ is an environmental pollutant. It is one of the aliphatic hydrocarbons that has wide spread uses in different industrial sectors as in production of chlorofluorocarbon refrigerants, foam blowing agents, cleaning compounds and organic solvents industry (Kalaf et al., 2006).

Carbon tetrachloride causes cellular damage in the kidney and other tissues such as the liver, heart, lung, testis, brain and blood (Pirinççioğlu et al, 2012).
This harmful effect is attributed to oxidative stress that results in generation of free radicals which involved in lipid peroxidation, accumulation of dysfunctional proteins and upregulation of nitric oxide (NO) production (Khan et al., 2009). Free radicals are neutralized by an elaborate antioxidant defense system of enzymes such as glutathione and superoxide dimutase (Abdel Moneim and El-Khadragy, 2013). 
NO is produced from L-arginine by the action of nitric oxide synthase (NOS) which exists in 3 isoforms, the neuronal NOS (nNOS), endothelial NOS (eNOS) and inducible NOS (iNOS) . All the three NOS isoforms are present in the renal cortex. The nNOS is expressed predominantly in tubular epithelial cells of macula densa. The eNOS is found in vascular endothelial cells. The iNOS is abundant in tubular epithelium, including proximal tubules, thick ascending limbs of Henle, distal convoluted tubule and intercalated cells of the collecting duct (Tojo et al., 1997 and Dautzenberg et al., 2011).

Chronic kidney disease represents a serious public health problem because of increased its prevalence. Continuous studies for finding a novel renoprotective agents are required (Hrenák et al., 2013).

Captopril is an angiotensin-converting enzyme (ACE) inhibitor containing sulfhydryl (SH) group. It was reported that it has a renoprotective action against renal damage induced by nephrotoxic agents such as cisplatin, gentamycin, doxorubicin and lead. This may be related to its free radicals scavenging due to its antioxidant effect (El-Sayed et al 2008, Rahman et al., 2009, Hrenák et al., 2013 and Ng et al. 2013).

Before establishing captopril as a therapeutic protective agent against nephrotoxicity in human, further studies should be conducted to confirm its nephroprotective effect in exposure to different toxins (Rahman et al., 2009).

In addition it was mentioned that captopril, angiotensin converting enzyme inhibitors and angiotensin receptor blockers were used to attenuate hepatic damage in both animal and human studies (Abbas et al., 2011).

The nigella sativa seeds contain fixed oil, volatile oil, alkaloids and saponin. The fixed oil is composed mainly of unsaturated fatty acids. The volatile oil has been shown to contain thymoquinone and many monoterpenes such as p-cymene, and $\alpha$ pinene (Raza et al., 2008).

The nigella sativa seeds/oils are used in folk (herbal) medicine all over the world as antiinflammatory, analgesic, antipyretic, antimicrobial, antineoplastic, anti asthmatic, antidiarrheal and dyslipidaemic. Both volatile oil and thymoquinone have been reported to give protection against nephrotoxicity and hepatotoxicity induced by chemicals. The beneficial effects are related to their antioxidant and cytoprotective actions by effect on mediators of inflammations (Ali and Blunden, 2003).

No available data are existing describing the role of captopril and nigella sativa oil in protection against $\mathrm{CCl} 4$ induced nephrotoxicty in rats.

\section{Aim of work}

This study was designed to evaluate the possible protective effect of single and combined administration of captopril and nigella sativa oil against carbon tetrachloride induced nephrotoxicty. In addition, the effects of these nephroprotective agents on oxidative stress markers and caspase- 3 were investigated.

\section{Materials and methods}

\section{(A) Chemicals}

Carbon tetrachloride (anlar grade) was obtained from ADWIC (Egypt). Captopril, reduced glutathione, Ellman's reagent [5,5-Dithiobis (2-nitrobenzoic acid), DTNB)] were purchased from Sigma Aldrich Co. (USA). All other chemicals were of analytical grades.

The nigella sativa oil was obtained from Cap Pharm Company, Egypt. Immunohistochemical kits for caspase-3 (CPP 32; AB-4 Rabbit Polyclonal Antibody) and Universal detection kit were obtained from Thermo Fisher Scientific (Fermont, California, USA).

\section{(B) Animals and Experimental design}

A total number of sixty four healthy adult male albino rats were used in this study and their weight ranged between (220-250) gms. They were obtained from the Animal House of Faculty of Medicine, Assuit University. The animals were housed in stainless steel cages with appropriate ventilation and temperature, fed on standard rodent pellet diet manufactured by the Egyptian Company for Oil and Soap (Cairo, Egypt) and tap water available ad libitum. These rats were maintained at constant daily light/dark periods for 12 hours. The rats were acclimatized to lab conditions prior to starting dosing for a period of 2 weeks. Dealing with the animals followed the regulations of the Animal house of Faculty of Medicine, Assiut University. Rats were weighed weekly in order to adjust the dose of chemicals/drugs according to their body weight. The duration of exposure to drugs/chemicals was 6 weeks, this was the time suggested by (Ma et al., 2014-b) to develop toxic effect on the kidneys.

The rats were divided into 8 groups (each group consisted of 8 rats).

Group I: (negative control). Rats were given ordinary rat diet and did not receive any drug. They were living in the same environmental conditions as the other groups to determine the normal values of the tested parameters.

Group II: Rats were used as positive control, given paraffin oil by i.p. injection and saline $(0.9 \%$ $\mathrm{NaCl}$ ) by gavage for 6 weeks to test the effect of the vehicle (solvent) on the rats (Tuncer et al., 2003 and Ahmed et al., 2011).

Group III: Rats were used as positive control, given captopril in a dose of $100 \mathrm{mg} / \mathrm{kg}$ daily by gavage for 6 weeks to test the effect of the treating drug on the rats.

Group IV: Rats were given nigella sativa oil in a dose of $4 \mathrm{ml} / \mathrm{kg}$ by gavage for 6 weeks to test the effect of the treating drug on rats (Abdel-Zaher et al., 2011).

Group V: Rats were injected with $\mathrm{CCl}_{4}$ three times/ week for 6 weeks in a dose of $20 \mu \mathrm{L} / 100 \mathrm{gm}$ b.w. i.p. (represents $1 / 8 \mathrm{LD}_{50}$ of $\mathrm{CCl}_{4}$ ) (Choi et al., 2011), diluted 1:6 in paraffin oil to induce nephrotoxicity (Ahmed et al., 2011).

Group VI: Rats were given captopril in a dose of $100 \mathrm{mg} / \mathrm{kg}$ daily by gavage concurrently with $\mathrm{CCl}_{4}$ i.p. for 6 weeks. This dose is the therapeutic dose 
which mentioned to give protection against nephrotoxicity induced by agents induces oxidative stress (Hrenák et al., 2013).

Group VII: Rats were given nigella sativa oil in a dose of $4 \mathrm{ml} / \mathrm{kg}$ by gavage in combination with $\mathrm{CCl}_{4}$ i.p. for 6 weeks. This was found to be the dose which gives protection against oxidative stress (AbdelZaher et al., 2011).

Group VIII: Rats were given captopril in a dose of $100 \mathrm{mg} / \mathrm{kg}$ along with nigella sativa oil in a dose of $4 \mathrm{ml} / \mathrm{kg}$ by gavage concurrently with $\mathrm{CCl}_{4}$ i.p. for 6 weeks.

\section{(C)Blood and tissue samples collection}

Blood samples were collected from all rat groups 24 hours after the last dose at the end of 6 weeks from the retro-orbital plexus of veins using a capillary pipette. The collected blood samples in glass tubes were centrifuged at $3000 \mathrm{rpm}$ for obtaining sera which stored at -20 until required for estimation of biochemical parameters.

The rats were sacrificed by decapitation after light ether anesthesia and dissected at the end of $6^{\text {th }}$ weeks. The kidneys were removed and divided into two parts; the first part was homogenized in ice cold saline. The kidney tissue homogenates were centrifuged at $3000 \mathrm{rpm}$ for 15 minutes. The resultant supernatant was stored at -70 for biochemical analysis. The second part divided into 2 portions, part was fixed in $10 \%$ formalin and processed for light microscopic examination and other part fixed in 5\% gluteraldehyde for electron microscopic examination (Khan et al., 2009).

\section{(D) Biochemical Measurements}

\section{(I) Assessment of renal function tests}

Measurement of serum urea, creatinine and uric acid was done by spectrophotometer using colorometric diagnostic kits (Biodiagnostic, Giza, Egypt).

-Serum urea was measured according to the method that described by Coulombe and Favreau (1963).

-Serum ceatinine was measured according to the method that described by Larsen (1972).

-Serum uric acid was measured according to the method that described by Whitehead et al. (1991).

\section{(II) Measurement of oxidative stress markers}

(1) Serum nitric oxide (NO) level assay

It is measured in the serum by assaying nitrate, one of the stable and non volatile end-products of NO oxidation. Serum nitrite concentration was measured using Griess reagents as described by Green and his coworker (1982). The absorbance measured at $550 \mathrm{~nm}$ using UV-visible spectrophotometer and calculate the serum NO level in samples from the standard curve and expressed as $\mu \mathrm{mol} / \mathrm{ml}$.

\section{(2) Lipid peroxidation assay}

Measurement of lipid peroxidation in kidney tissue was carried out by the method described by Ohkawa, et al. (1979). Lipid peroxidation is an oxidative stress marker, was determined by measuring the level of the Malonic aldehyde (MDA) in the kidney tissue homogenates. The MDA is an end product of lipid peroxidation and its level was determined by use of thiobarbituric acid reactive substances (TBARS) method. The TBARS which formed in each of the samples was assessed spectrophotmetrically by measuring optical density of the supernatant at $532 \mathrm{~nm}$ against a reagent blank and expressed as $\mu \mathrm{mol} / \mathrm{mg}$ protein.

(3) Reduced glutathione (GSH) assay

Estimation of intracellular GSH content of neutralized supernatant renal tissue was assayed using Ellman's reagent (Ellman, 1959) which composed of [5,5-Dithiobis (2-nitrobenzoic acid), DTNB solution)] which measured spectrophotometrically according to the method described by Griffith (1980). A standard reference curve was prepared for each assay. The optical density of the supernatant measured at $412 \mathrm{~nm}$. Results were expressed as $\mu \mathrm{nmol} / \mathrm{g}$ protein. The protein contents were determined by using the method described by Lowry, et al. (1951).

(4) Superoxide dimutase (SOD) assay

The assay of SOD activity in the supernatant of renal homogenate was determined spectrophotometrically by using commercial kit utilizing a dye that produces a water soluble formazine upon reduction with a superoxide anion. The rate of the reduction with a superoxide anion is inhibited by SOD. The higher the activity of SOD is the less formation of formazin and the lower the absorption value. The optical density of the supernatant measured at $480 \mathrm{~nm}$. Results were expressed as $\mu / \mathrm{mg}$ protein for tissue supernatant according to the method described by Kono (1978).

\section{(E) Histopathological analysis}

(1) Light microscopic examination

The specimens were taken from the kidneys of all groups and were fixed in formalin 10\%. Paraffin sections were prepared and stained with Haematoxylin and Eosin and PAS (Periodic- acid Schiff) stains (Durary and Wallington, 1980).

\section{(2) Immunohistochemical examination}

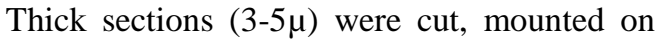
poly L-lysine coated slides. Deparaffinizion was done in xylene and rehydration in descending grades of alcohol. Hydrogen peroxide was added for 15 minutes to reduce non specific background staining due to endogenous peroxidase then the specimens were washed 2 times in phosphate buffer saline (PBS) for 5 minutes. Ultra V Block was applied and incubated for 5 minutes at room temperature to block non specific background staining. The slides were rinsed in PBS then in citrate buffer in a microwave oven for 5 minutes. The slides were left to cool down for 20 minutes then washed 4 times in PBS. Caspase- 3 (CPP32) Ab-4 rabbit polyclonal antibody, Thermo scientific-USA) was added for one hour at room temperature in a dilution of 1:100, after that washed 4 times in PBS. Next step, Biotinylated Goat AntiPolyvalent (secondary antibody) was applied for all the slides and incubated for 30 minutes at room temperature, afterward they washed 4 times in PBS. Streptavidin Peroxidase was applied and incubated for 10 minutes at room temperature, after that rinsed in 
PBS. One to two drops of DAB chromogen (Diaminobenzidine) was added for 5-15 minutes and washed in distilled water for 5 minutes. Counterstaining by Meyer's $\mathrm{Hx}$ was followed by washing in tap water. Dehydration by ascending grades of alcohol, clearing for few seconds, mounting using coverslip and a permanent mounting media (Cerson, 1990). For negative control staining, some sections were incubated with PBS instead of the primary antibody. No immunoreactivity was present in these sections. Positive control sections for caspase-3 was from tonsil.

\section{(3) Transmission electron microscopy}

Immediately after the rats being sacrificed, 1012 small pieces of the kidney cortex were fixed in 5\% gluteraldehyde for 24 hours. The specimens were after that washed in 3-4 changes of cacodylate buffer (PH 7.2) for 20 minutes in every change and post fixed in cold $1 \%$ osmium tetroxide for two hours. Next they were washed in four changes of cacodylate buffer for 20 minutes each. Dehydration was done by using ascending grades of alcohol (30, 50, 70, 90 and absolute alcohol) each for two hours. Clearing in propylene oxide followed by embedding in Epon. These samples were kept in incubator at 35 degree for one day, then at 45 degree for another day and lastly for three days at 60 degree (Gupta,1983). Semithin sections (0.5-lum) were prepared by using LKB ultra microtome. The sections were stained by Toluidine blue, examined by light microscope and photographed. Ultra-thin sections (500800A) from selected areas of trimmed blocks were made and collected on copper grids. The ultrathin sections were contrasted in uranyle acetate for 10 minutes, lead citrate for 5 minutes and examined by electron microscope " JEM-100 CXII, Japan " in the electron microscope unit of Faculty of Medicine, Assiut University.

\section{(F) Stastical Analysis}

The data were presented in the form of mean \pm standard deviation (SD). Statistical analysis was done using one way analysis of variance (one-way ANOVA) was done to compare between means of all different rat groups using SPSS computer program, Version 20. The difference was non significant at $\mathrm{P} \geq 0.05$, significant at $\mathrm{P}<0.05$ and highly significant at $\mathrm{P} \leq 0.01$ ) (Kirkwood and Sterner, 2003).

\section{Results}

\section{(A) Biochemical assays}

\section{(I) Kidney function tests}

Table (1): shows one way ANOVA statistical analysis of serum urea, creatinine and uric acid levels in all rat groups.

The mean of serum levels of urea, creatinine and uric acid (mg/dl) were highly significantly increased in $\mathrm{CCl}_{4}$ treated group $(61.2 \pm 2.4),(0.622 \pm$ $0.04)$ and $(8.17 \pm 0.44)$ respectively when compared to control group I $(23.8 \pm 1.9),(0.338 \pm 0.01)$ and $(4.96 \pm$ $0.24)$ and other control groups (P. value $\leq 0.01)$.

There were highly significant decrease in the mean of serum urea, creatinine and uric acid levels on administration of captopril with $\mathrm{CCL}_{4}(47.1 \pm 2.5)$,
$(0.458 \pm 0.02)$ and $(5.85 \pm 0.29)$ respectively $(P$. value $\leq 0.01)$. There were highly significant decrease in the mean of serum urea, creatinine and uric acid levels on administration of nigella sativa oil with $\mathrm{CCL}_{4}(45.3 \pm$ $2.4)(0.452 \pm 0.02)$, and $(5.95 \pm 0.29)$ respectively ( $P$. value $\leq 0.01)$. A highly significant decrease in the elevated serum level of urea, creatinine and uric acid was found in combination of nigella sativa oil+ captopril treated group $(35.5 \pm 2.3),(0.364 \pm 0.014)$ and $(5.32 \pm 0.15)$ respectively when compared with $\mathrm{CCl}_{4}$ treated group $(\mathrm{P}$. value $\leq 0.01)$. There was no significant statistical difference between the mean of serum urea, creatinine and uric acid levels in all control rat groups (I, II, III and IV) (P. value $\geq 0.05$ ).

\section{(II) Serum nitric oxide (NO) level}

Table (2): shows one way ANOVA statistical analysis of serum NO levels in all rat groups. The mean of serum NO level $(\mu \mathrm{mol} / \mathrm{L})$ was highly significantly increased in $\mathrm{CCl}_{4}$ treated group $(28 \pm 2.1)$ as compared to control group $(16.3 \pm 1.3)(\mathrm{P}$. value $\leq 0.01)$. There was a highly significant decrease in the elevated serum NO level to near control value in rats which administrated of $\mathrm{CCL}_{4}$ concomitant with captopril alone $(22.3 \pm 2)$ or nigella sativa oil alone $(21.4 \pm 1.8)$ and captopril combined with nigella sativa oil (19.2 \pm 1.6) when compared to $\mathrm{CCl}_{4}$ treated group $(28 \pm 2.1)$ (P. value $\leq 0.01)$. There was no significant statistical difference between the mean of in serum NO level of all control rat groups (I, II, III and IV) (P. value $\geq$ $0.05)$.

\section{(III) Serum lipid peroxidation (TBARS) level}

Table (3): shows one way ANOVA statistical analysis of TBARS level (nmol/mg protein) in kidney tissues of rats. The mean of TBARS level was a highly significantly increased in $\mathrm{CCL}_{4}$ treated group $(0.912 \pm$ $0.07)$ as compared to control group $(0.262 \pm 0.01)$. There was a highly significant decrease in the mean of serum TBARS level in rat groups treated with nigella sativa oil alone $(0.572 \pm 0.02)$, captopril alone $(0.632 \pm$ $0.01)$ and when nigella sativa oil combined with captopril $(0.486 \pm 0.01)$. There was no significant statistical difference between the mean of TBARS level in all control rat groups (I, II, III and IV) (P. value $\geq$ $0.05)$.

\section{(IV) Kidney reduced glutathione (GSH) level}

Table (4): shows one way ANOVA statistical analysis of GSH level ( $\mu \mathrm{nmol} / \mathrm{g}$ protein) in the kidneys in all rat groups. There was a highly significantly decrease in the mean of GSH level in $\mathrm{CCL}_{4}$ treated group (1.9 \pm $0.07)$ as compared to control group $(4.8 \pm 0.01)$. There was a highly significant increase in the mean of decreased serum GSH level in rat group treated with nigella sativa oil alone $(3.21 \pm 0.01)$, captopril alone $(2.9 \pm 0.01)$ and when nigella sativa oil combined with captopril $(3.75 \pm 0.01)$ when compared to $\mathrm{CCl}_{4}$ treated group $(\mathrm{P}$. value $\leq 0.01)$. There was no significant statistical difference between the mean of kidney GSH level in all control rat groups (I, II, III and IV) (P. value $\geq 0.05$ ).

(V) Kidney superoxide dimutase level (SOD)

Table (5): shows one way ANOVA statistical analysis of SOD level (U/mg protein) in kidneys of in all rat 
groups. The mean of SOD level was a highly significantly decreased in $\mathrm{CCL}_{4}$ treated group $(0.16 \pm$ $0.07)$ as compared to control group $(0.623 \pm 0.01)$ (P. value $\leq 0.01)$. There was a highly significant increase in the mean of decreased serum GSH level in rat groups treated with nigella oil alone $(0.49 \pm 0.01)$, captopril alone $(0.45 \pm 0.01)$ and when nigella sativa oil combined with captopril $(0.57 \pm 0.01)$ when compared to $\mathrm{CCl}_{4}$ treated group ( $\mathrm{P}$. value $\leq 0.01$ ). There was no significant statistical difference between the mean of control rat groups (I, II, III and IV) in kidney SOD level (P. value $\geq 0.05$ ).

Table (1): One Way ANOVA statistical analysis of serum urea, creatinine and uric acid levels in all rat groups. Each group composed of 8 rats.

\begin{tabular}{|l|c|c|c|}
\multicolumn{1}{|c|}{ Groups } & $\begin{array}{c}\text { Urea (mg/d) } \\
\text { Mean } \pm \text { SE }\end{array}$ & $\begin{array}{c}\text { Creatinine (mg/dl) } \\
\text { Mean } \pm \text { SE }\end{array}$ & $\begin{array}{c}\text { Uric Acid (mg/dl) } \\
\text { Mean } \pm \text { SE }\end{array}$ \\
\hline G. I: negative control & $23.8 \pm 1.9$ & $0.338 \pm 0.01$ & $4.96 \pm 0.24$ \\
\hline G. II: paraffin oil (positive control) & $25.1 \pm 1.6$ & $0.342 \pm 0.02$ & $4.86 \pm 0.25$ \\
\hline G.III: captopril & $24.3 \pm 1.7$ & $0.339 \pm 0.01$ & $4.96 \pm 0.24$ \\
\hline G.IV: nigella sativa oil & $24.11 \pm 1.6$ & $0.337 \pm 0.015$ & $4.86 \pm 0.25$ \\
\hline G. V: $\mathrm{CCl}_{4}$ & $61.2 \pm 2.4$ oo & $0.622 \pm 0.04$ oo & $8.17 \pm 0.44$ oo \\
\hline G. VI: $\mathrm{CCl}_{4}+$ captopril & $47.1 \pm 2.5 * *$ & $0.458 \pm 0.02 * *$ & $5.85 \pm 0.29 * *$ \\
\hline G. VII: $\mathrm{CCl}_{4}+$ nigella sativa oil & $45.3 \pm 2.4 * *$ & $0.452 \pm 0.02 * *$ & $5.95 \pm 0.29 * *$ \\
\hline G.VIII: $\mathrm{CCl}_{4}+$ captopril + nigella sativa oil & $35.5 \pm 2.3 * *$ & $0.364 \pm 0.01 * *$ & $5.32 \pm 0.15^{* *}$ \\
\hline
\end{tabular}
oo Highly significant, in group V versus groups I,II, III and IV (P. value $\leq=0.01)$, ** Highly significant groups VI,VII and VIII versus group $V(P$. value $\leq=0.01)$.

Table (2): One Way ANOVA statistical analysis of serum nitric oxide levels in all rats groups. Each group composed of 8 rats.

\begin{tabular}{|l|c|}
\hline \multicolumn{1}{|c|}{ Groups } & $\begin{array}{c}\text { Serum NO }(\boldsymbol{\mu m o l} / \mathbf{m l}) \\
\text { Mean } \pm \text { SE }\end{array}$ \\
\hline G. I: negative control & $16.3 \pm 1.3$ \\
\hline G. II: paraffin oil (positive control) & $16.6 \pm 1.2$ \\
\hline G.III: captopril & $16.5 \pm 1.1$ \\
\hline G.IV: nigella sativa oil & $16.4 \pm 1.1$ \\
\hline G. V: $\mathrm{CCl}_{4}$ & $28 \pm 2.1$ oo \\
\hline G. VI: $\mathrm{CCl}_{4}+$ captopril & $22.3 \pm 2 * *$ \\
\hline G. VII: $\mathrm{CCl}_{4}+$ nigella sativa oil & $21.4 \pm 1.8^{* *}$ \\
\hline G.VIII: $\mathrm{CCl}_{4}+$ captopril + nigella sativa oil & $19.2 \pm 1.6^{* *}$ \\
\hline
\end{tabular}

oo Highly significant, in group V versus groups I,II, III and IV (P. value $\leq=0.01)$, ** Highly significant groups VI,VII and VIII versus group V(P. value $\leq=0.01)$.

Table (3): One Way ANOVA statistical analysis of lipid peroxidation (TBARS) level $(\mathbf{n m o l} / \mathrm{ml})$ in

kidneys of all rats groups. Each group composed of 8 rats.

\begin{tabular}{|l|l|}
\hline \multicolumn{1}{|c|}{ Groups } & TBARS (nmol/mg protein) (Mean \pm SE) \\
\hline G. I: negative control & $0.262 \pm 0.01$ \\
\hline G. II: paraffin oil (positive control) & $0.266 \pm 0.01$ \\
\hline G.III: captopril & $0.270 \pm 0.01$ \\
\hline G.IV: nigella sativa oil & $0.268 \pm 0.01$ \\
\hline G. V: $\mathrm{CCl}_{4}$ & $0.912 \pm 0.07 \mathrm{oo}$ \\
\hline G. VI: $\mathrm{CCl}_{4}+$ captopril & $0.572 \pm 0.02 * *$ \\
\hline G. VII: $\mathrm{CCl}_{4}+$ nigella sativa oil & $0.632 \pm 0.01 * *$ \\
\hline G.VIII: $\mathrm{CCl}_{4}+$ captopril + nigella sativa oil & $0.486 \pm 0.01 * *$ \\
\hline
\end{tabular}

oo Highly significant, in group V versus groups I,II, III and IV (P. value $\leq=0.01)$, ** Highly significant groups VI,VII and VIII versus group $V(P$. value $\leq=0.01)$.

Table (4): One Way ANOVA statistical analysis of reduced glutathione level (GSH) (nmol/ml) in kidneys of all rats groups. Each group composed of 8 rats.

\begin{tabular}{|l|l|}
\hline \multicolumn{1}{|c|}{ Groups } & GSH $(\boldsymbol{\mu n m o l} / \mathbf{g}$ protein) $($ Mean \pm SE) \\
\hline G. I: negative control & $4.6 \pm 0.01$ \\
\hline G. II: paraffin oil (positive control) & $4.9 \pm 0.01$ \\
\hline G.III: captopril & $4.8 \pm 0.01$ \\
\hline G.IV: nigella sativa oil & $4.7 \pm 0.01$ \\
\hline G. V: $\mathrm{CCl}_{4}$ & $1.9 \pm 0.07$ oo \\
\hline G. VI: $\mathrm{CCl}_{4}+$ captopril & $3.21 \pm 0.01^{* *}$ \\
\hline G. VII: $\mathrm{CCl}_{4}+$ nigella sativa oil & $2.7 \pm 0.01 * *$ \\
\hline G.VIII: $\mathrm{CCl}_{4}+$ nigella sativa oil + captopril & $3.75 \pm 0.01^{* *}$ \\
\hline
\end{tabular}

oo Highly significant, in group V versus groups I,II, III and IV (P. value $\leq=0.01)$, ** Highly significant groups VI,VII and VIII versus group V(P. value $\leq=0.01)$. 
Table (5): One Way ANOVA statistical analysis of superoxide dimutase level (SOD) (nmol/ml) in kidneys of all rats groups. Each group composed of 8 rats.

\begin{tabular}{|c|c|}
\hline Groups & $\begin{array}{c}\text { SOD }(\text { U/mg protein }) \\
(\text { Mean } \pm \text { SE })\end{array}$ \\
\hline G. I: negative control & $0.63 \pm 0.01$ \\
\hline G. II: paraffin oil (positive control) & $0.61 \pm 0.01$ \\
\hline G.III: captopril & $0.62 \pm 0.01$ \\
\hline G.IV: nigella sativa oil & $0.64 \pm 0.01$ \\
\hline G. V: $\mathrm{CCl}_{4}$ & $0.16 \pm 0.07$ oo \\
\hline G. VI: $\mathrm{CCl}_{4}+$ captopril & $0.49 \pm 0.01 * *$ \\
\hline G. VII: $\mathrm{CCl}_{4}+$ nigella sativa oil & $0.44 \pm 0.01 * *$ \\
\hline G.VIII: $\mathrm{CCl}_{4}+$ nigella sativa oil + captopril & $0.57 \pm 0.01 * *$ \\
\hline
\end{tabular}

oo Highly significant, in group V versus groups I,II, III and IV (P. value $\leq=0.01)$, ** Highly significant groups VI,VII and VIII versus group V(P. value $\leq=0.01)$.

\section{(B) Histopathological Examination}

\section{I-Light Microscopic Examination}

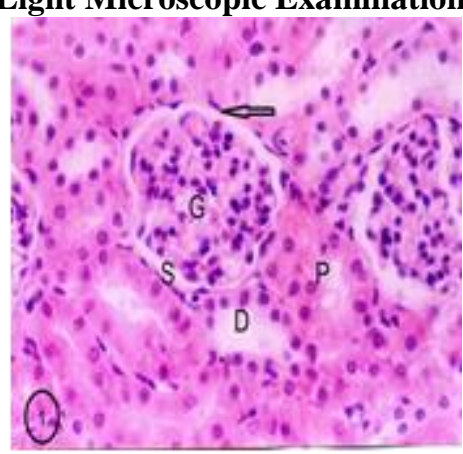

(Fig.1): A photomicrograph of a section of the renal cortex of control rat groups (I, II, III and IV). The renal corpuscle shows the glomerulus (G) with its capillary tufts surrounded by a narrow capsular space (S) and Bowman's capsule (arrow). Proximal convoluted tubules (P) have a narrow lumen and $a$ highly acidophilic cytoplasm. Distal convoluted tubules (D) have a wider lumen and less acidophilic cytoplasm. H\&E x400

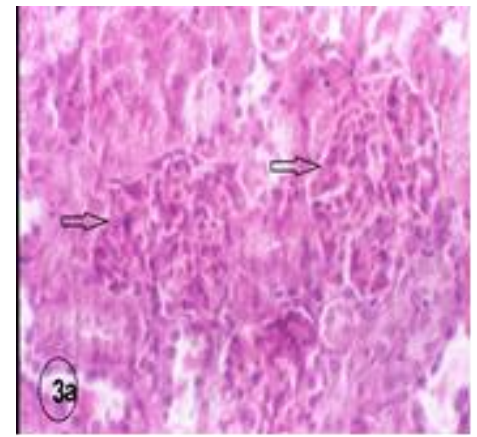

(Fig.3): (a)-A photomicrograph of the renal cortex of group $V$ rats, showing obliteration of the capsular space (arrow).

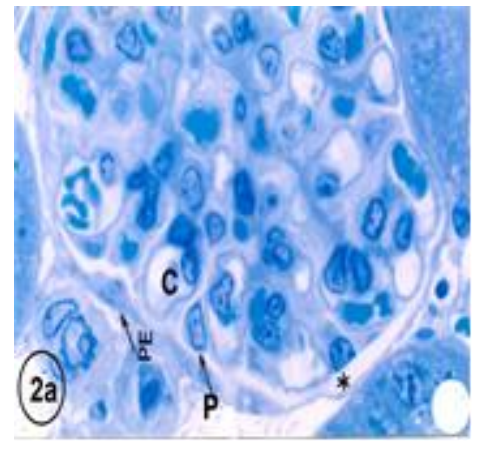

(Fig.2-a): A photomicrograph of the renal cortex of control rat groups (I, II, III and IV). showing a part of a renal corpuscle. Glomerular capillaries are defined by the prominent glomerular basement membrane (C). Podocytes (P) have pale nuclei and pale stained cytoplasm. Note the mesangeal cell (M) and the squamous cells of Bowman's capsule (arrow).

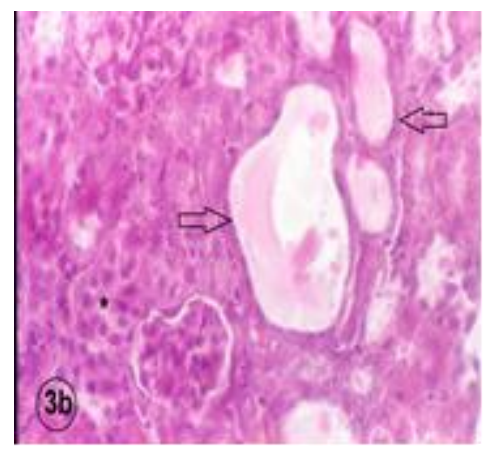

(Fig.3): (b): A photomicrograph of group III rats, showing dilatation of some tubules (arrow) with obliteration of the lumen of others by exfoliated cells (asterisk). H\&E x400

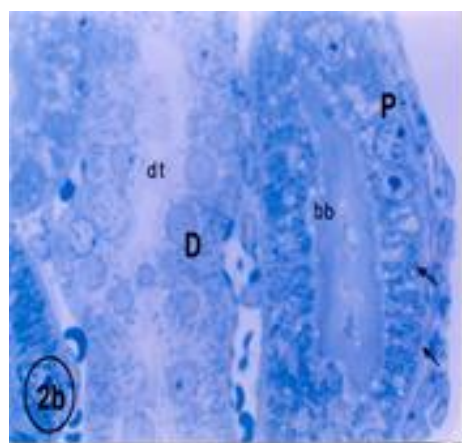

(Fig.2b): A photomicrograph of the renal cortex of control rat groups (I, II, III and IV). The cells of proximal convoluted tubules $(P)$ have apical brush border (bb) and well-formed basal striations (arrow). Their nuclei are central and pale with prominent nucleoli. The distal convoluted tubules (D) have pale apical nuclei with no brush border.

Toluidine blue x1000

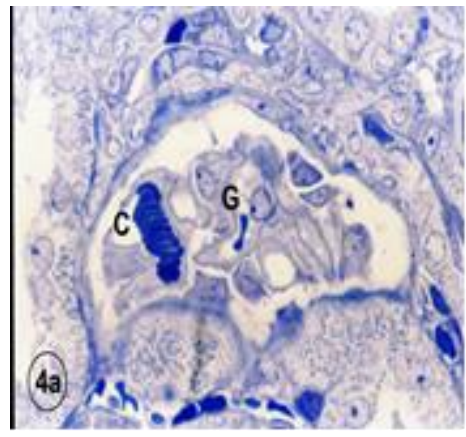

(Fig.4): (a)- A photomicrograph of the renal cortex of group $V$ rats, showing a renal corpuscle with atrophic glomeruli (G).Note congestion of glomerular capillaries $(C)$. 


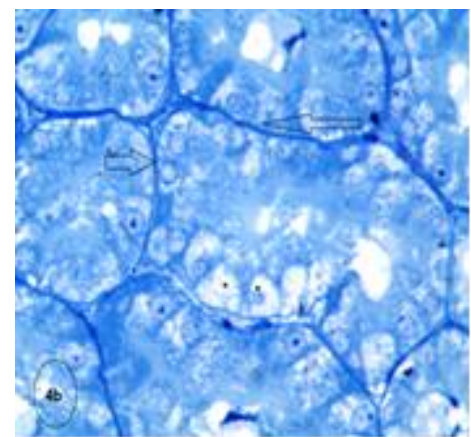

(Fig.4): (b)-

A photomicrograph of of group IV rats, showing vacuolation of the cells of some kidney tubules (asterisk). Note: thickening of the basement membrane of some kidney tubules (arrow). Toluidine blue x1000

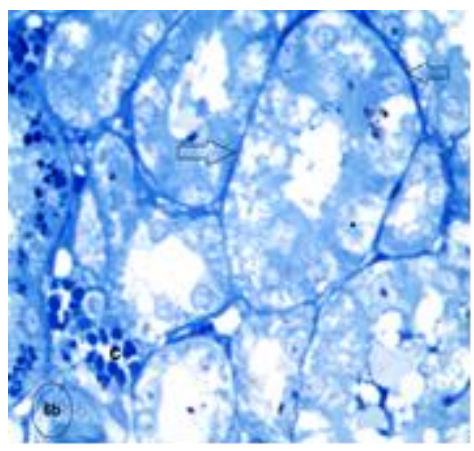

(Fig.6): b- A photomicrograph of the same group showing some tubules with vacuolated cytoplasm (asterisk) and thickened basement membrane (arrow). Note: a congested blood vessel is seen $(C)$. Toluidine blue $x$ 1000

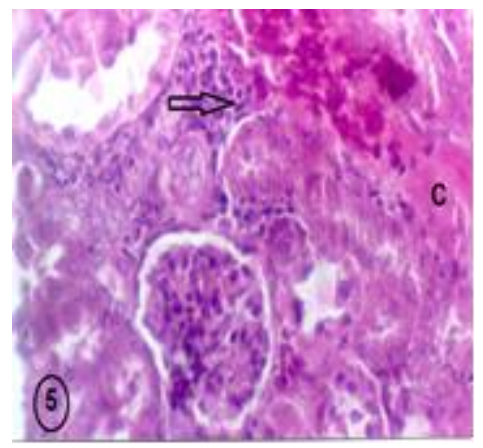

(Fig.5): Aphotomicrograph of the renal cortex of group VI rats, showing normal appearance of the renal corpuscle. Note: Focal cellular infiltration (arrow) with congested blood vessels(c). (H \&E) x400

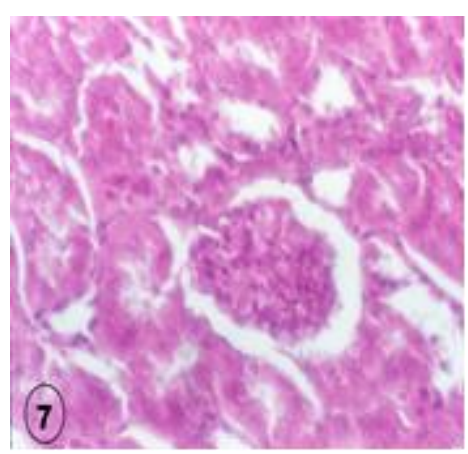

(Fig.7): A photomicrograph of the renal cortex of group VI rats, showing normal appearance of the renal cortex.
H\&E x 400

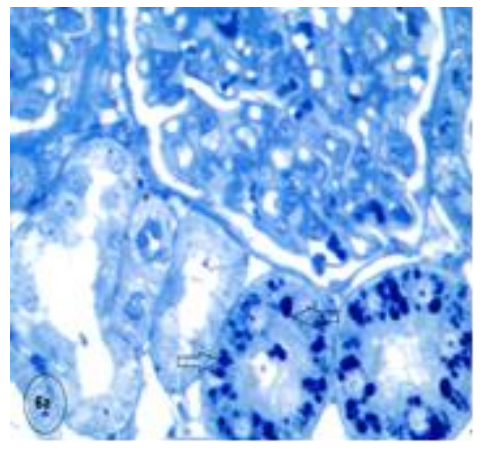

(Fig.6): a-A photomicrograph of the renal cortex of group VI rats, showing normal appearance of the renal corpuscle. Note: the proximal tubules show many deeply stained granules (arrow).

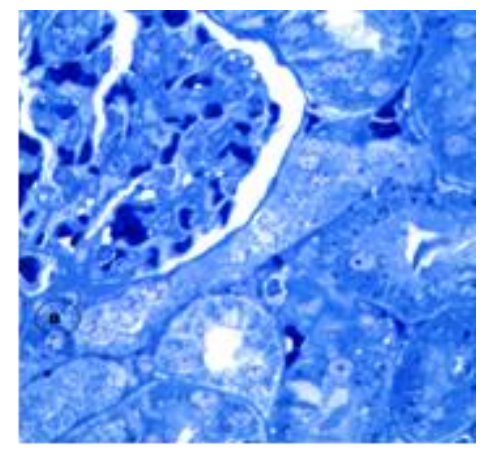

(Fig.8): - A photomicrograph of the renal cortex of group VII rats, showing a normal appearance of the renal cortex. Toluidine blue x 1000

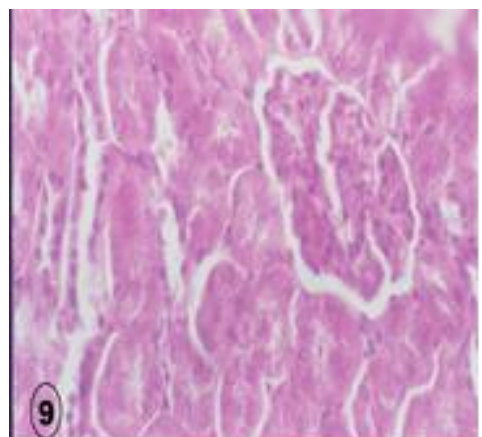

(Fig.9): A photomicrograph of the renal cortex of group VIII, showing normal appearance of the renal cortex.

H\&E x400

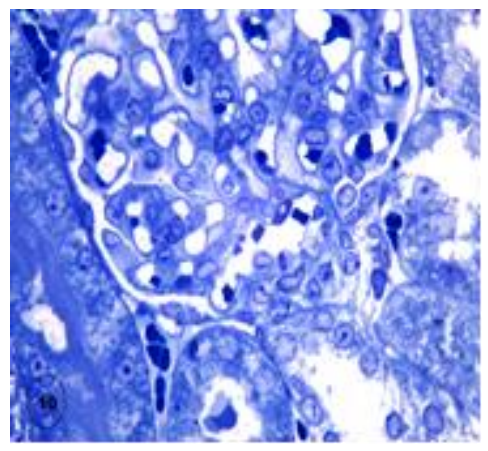

(Fig.10): A photomicrograph of the renal cortex of group VIII, showing normal appearance of the renal cortex.

Toluidine blue $\mathbf{x 1 0 0 0}$ 


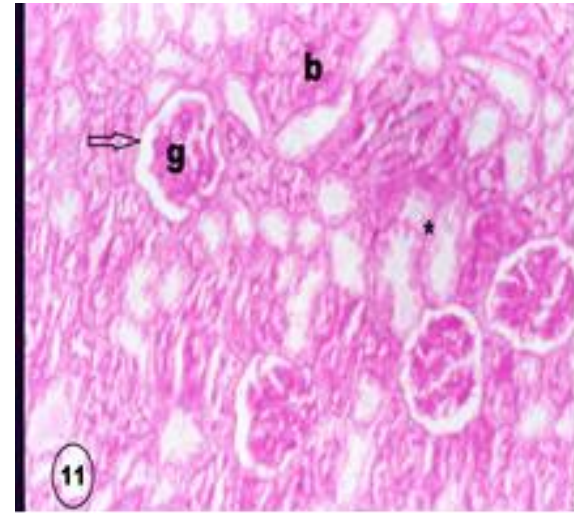

(Fig. 11): A photomicrograph of a section of the renal cortex of control rat groups (I, II, III and IV rats showing PAS-positive reaction along the basement membranes of the renal tubules (asterisk), the parietal layer of Bowman's capsule (arrow) and glomerular capillaries (g) and the apical brush border of the proximal convoluted tubules (b).

(PAS x400).

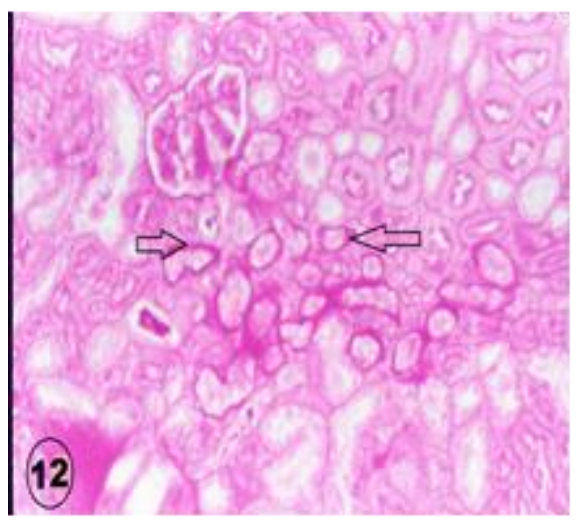

(Fig.12): A photomicrograph of a section of the renal cortex of group $V$ rats showing thickening in the basement membrane of many kidney tubules (arrow). (PAS x400).

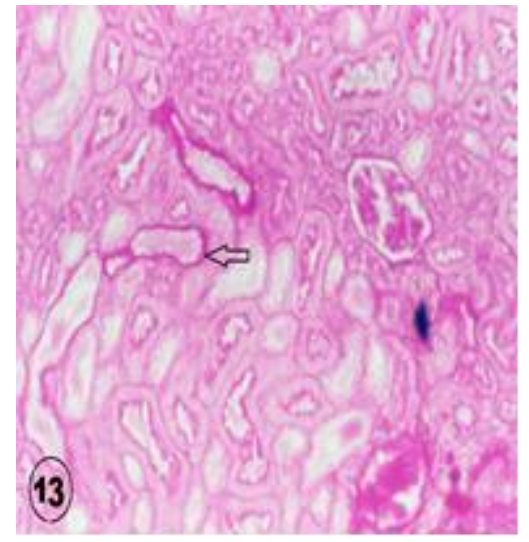

(Fig.13): A photomicrograph of a section of the renal cortex of group VI rats showing decrease in thickening of basement membrane of kidney tubules compared with group III.

(PAS x400).

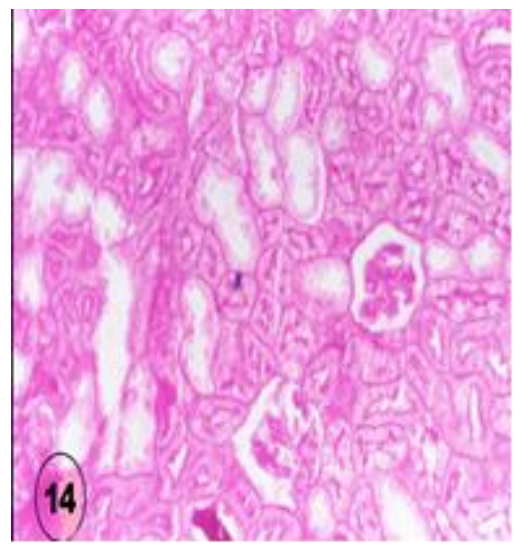

(Fig.14): A photomicrograph of a section of the renal cortex of group VII rats showing mild thickening in the basement membrane of some kidney tubules compared with group III. (PAS x400).

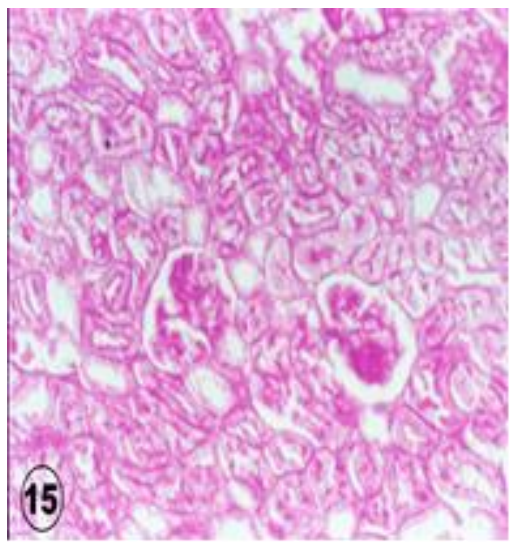

(Fig.15): A photomicrograph of a section of the renal cortex of group VIII showing normal appearance of kidney tubules. (PAS x400). 
(II) Immuno-histochemical Examination

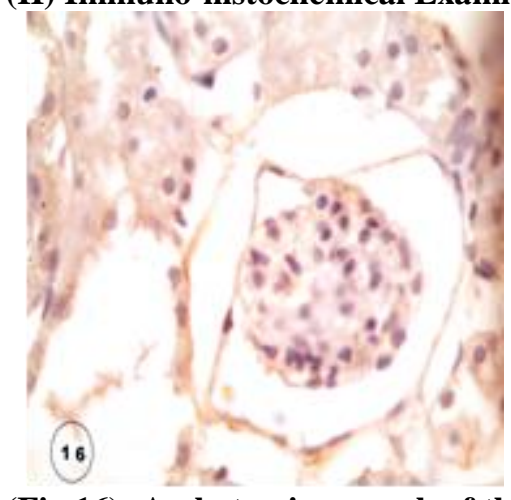

(Fig.16): A photomicrograph of the renal cortex of control rat groups (I, II, III and IV rats). The caspase3 immunostaining is virtually absent in the renal corpuscle and the tubules.

(Caspase-3 immunostaining x1000)

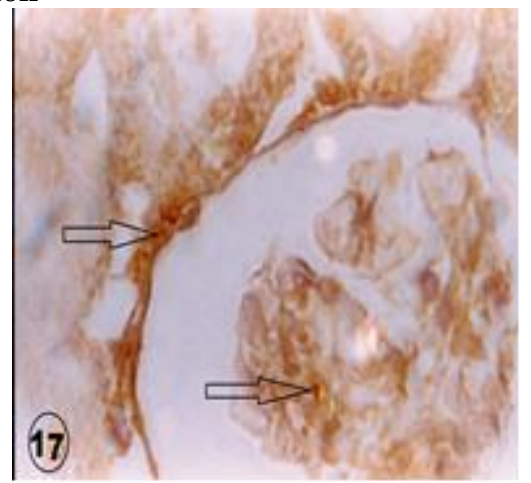

(Fig.17): A photomicrograph of the renal cortex of group $V$ rats. The caspase-3 immunostaining is observed in the renal corpuscle and in the kidney tubules (arrows).

(Caspase-3 immunostaining x1000)

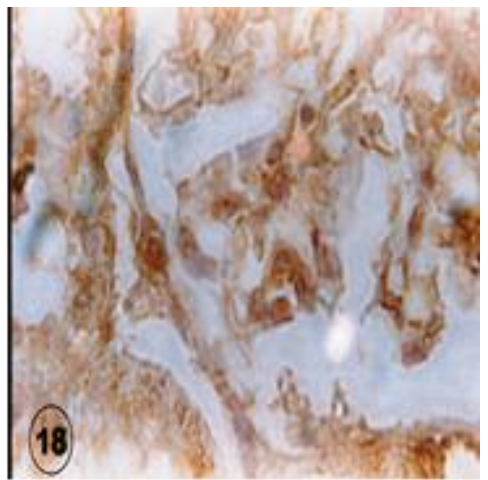

(Fig.18): A photomicrograph of the renal cortex of group VI rats. Decrease in the reaction for caspase-3 immunostaining in the renal corpuscle and kidney tubules.

(Caspase-3 immunostaining x1000)

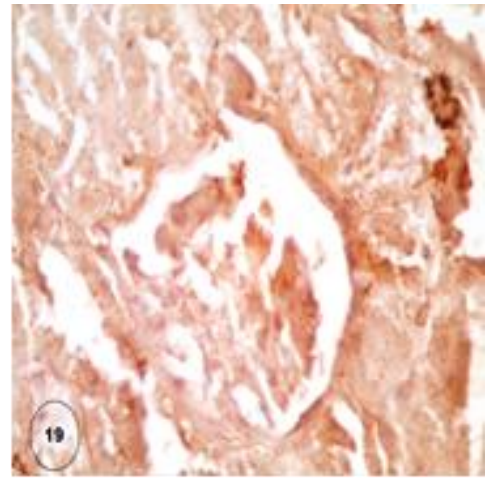

(Fig.19): A photomicrograph of the renal cortex of group VII rats. A noticeable reduction of caspase-3 immunostaining in the renal corpuscle and kidney tubules.

(Caspase-3 immunostaining x1000)

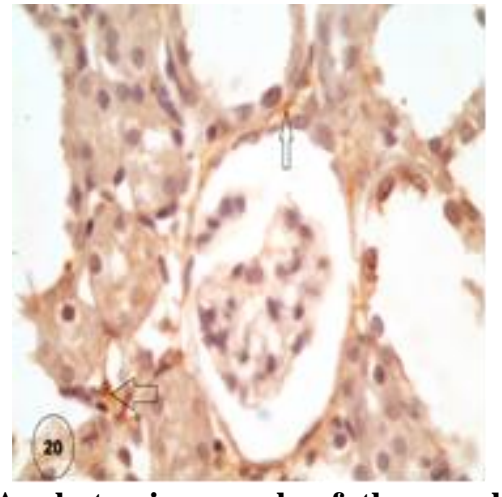

(Fig.20): A photomicrograph of the renal cortex of group VIII rats: showing marked decrease in caspase -3 immunostaining in the renal corpuscle and kidney tubules.

(Caspase-3 immunostaining x1000)

\section{(III) Transmission Electron Microscopy Examinatio}

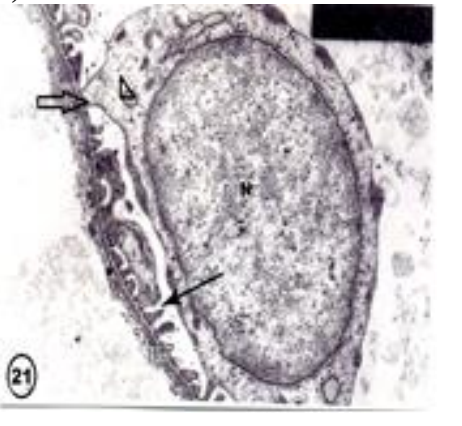

(Fig.21): Electron micrograph of the renal cortex of control rat groups (I, II, III and IV ) showing a podocyte with central nucleus $(N)$ with characteristic well-formed primary (arrow head) and secondary foot processes(arrow) resting on the glomerular basement membrane - Note, the glomerular filteration barrier (astrick) with its three components (fenestrated endothelium, glomerular basement membrane, and slit diaphragms.with uniform thickness. $\mathrm{X} 8000$.

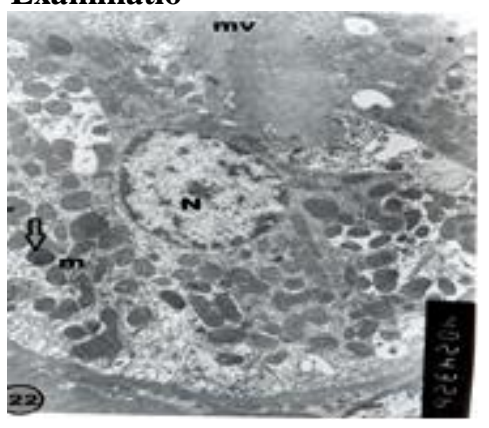

(Fig.22): Electron micrograph of the proximal convoluted tubule of control rat groups (I, II, III and IV) showing a spherical basal euchromatic nucleus (N) and elongated radially arranged mitochondria (m).Note the long apical microvilli (mv) and electron dense lysosomes (arrow). $\quad$ X 4000.

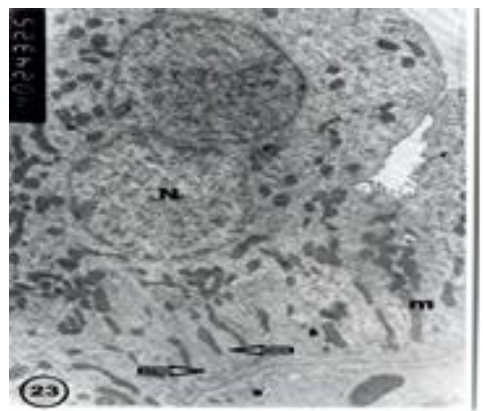

(Fig.23): Electron micrograph of the distal convoluted tubule of control rat groups (I, II, III and IV) showing regular basal infoldings (arrow), numerous elongated mitochondria (m) and euchromatic nuclei (N). $\quad$ X 4000. 


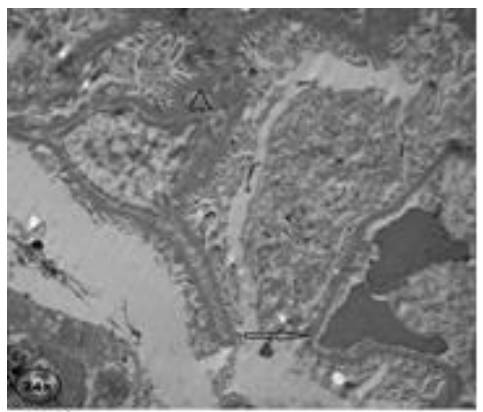

(Fig.24): 24a-Electron micrograph of the renal cortex of group $V$ rats, showing part of the podocyte with broadening of foot processes (arrow) with irregular spacing between them. Also, focal thickening of the basement membrane is also observed (arrow head). X 4800.

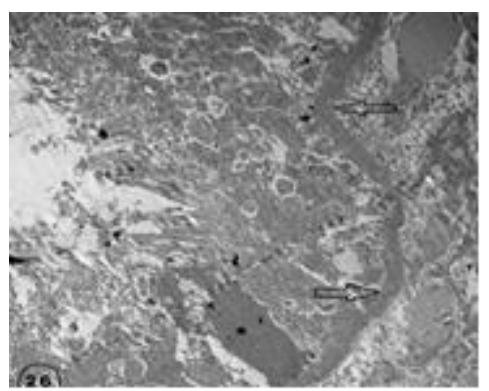

(Fig.26): Electron micrograph of the proximal convoluted tubule of group $V$ rats showing thickened irregular basement membrane (arrow) with electron dense cytoplasm (astrick). X 3600.

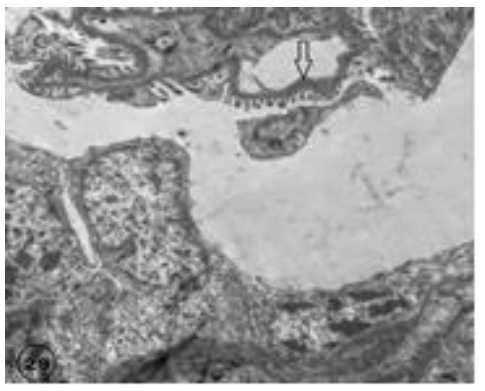

(Fig.29): Electron micrograph of the renal cortex of group VI rats showing focal broadening of the foot processes with irregularity and thickening of the glomerular basement membrane (arrow). X4800

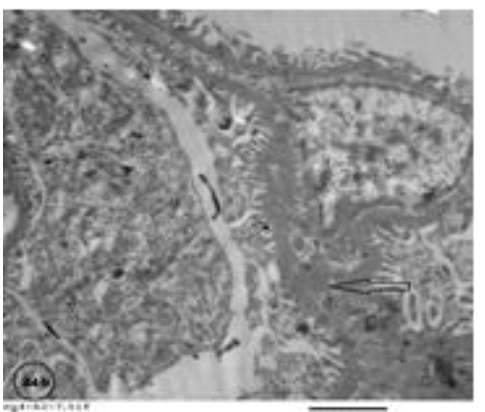

(Fig.24): b-Magnification of the previous micrograph, showing focal thickening and irregularity of the gomerular membrane (arrow). X 7200.

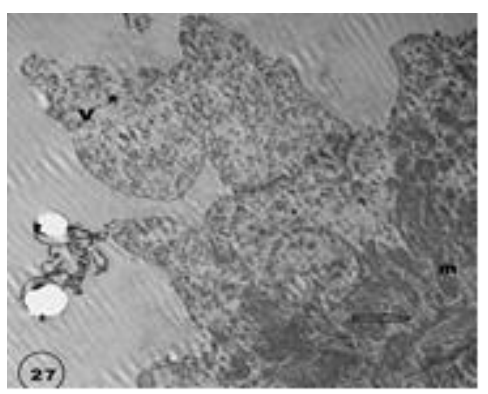

(Fig.27): Electron micrograph of the distal convoluted tubule of group V rats showing swollen cells with apical cytoplasmic bleb (astrick) and vacuolated apical cytoplasm (v). Note the preservation of basal infoldings (arrow) and organized mitochondria (m). X 3600.

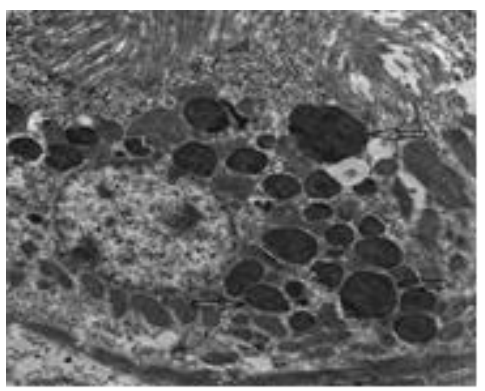

(Fig.30): Electron micrograph of the proximal convoluted tubule of group VI rats showing many irregular electron dense lysosomes (arrow).

X 4800 .

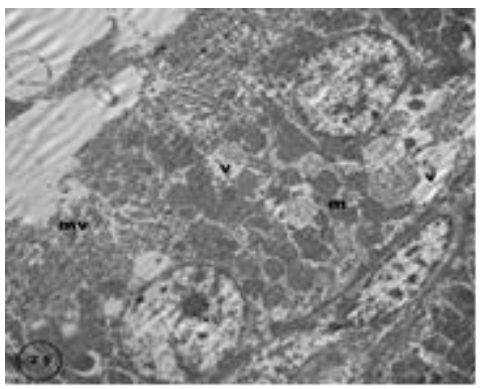

(Fig,25): Electron micrograph of the proximal convoluted tubule of group V rats showing short and irregular apical micovilli (mv). The mitochondria (m) are swollen and irregularly arranged in between large cytoplasmic vacuoles (v). X 3600.

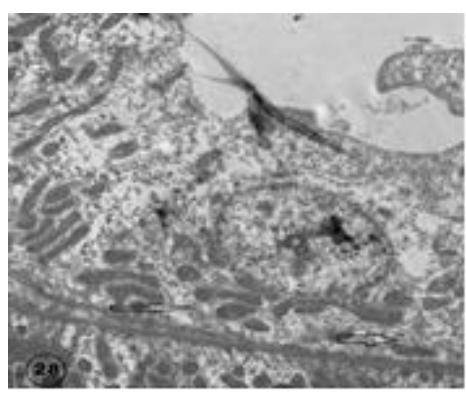

(Fig.28): Electron micrograph of the distal convoluted tubule of group V rats showing few irregular basal infoldings (arrow). X 4800

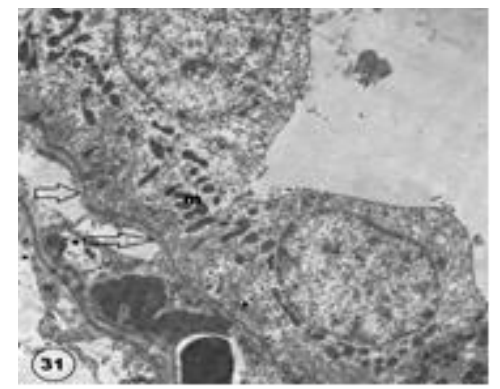

(Fig.31): Electron micrograph of the distal convoluted tubule of group VI rats showing irregular basement membrane (arrow) with electron dense mitochondria (m). X 4800. 


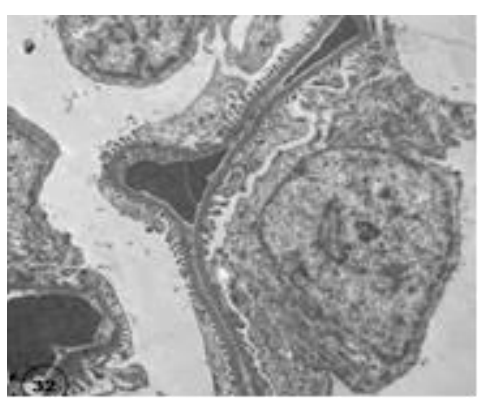

(Fig.32): Electron micrograph of the kidney cortex of group VII rats showing less broadening of foot processes with decrease in the thickening and irregularity of the basement membrane. X4800

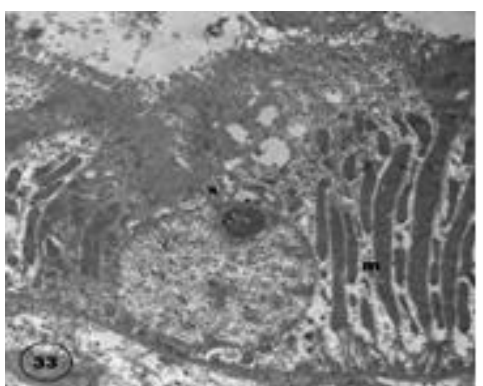

(Fig.33): Electron micrograph of the proximal convoluted tubule of group VII rats, showing elongated radially arranged mitochondria (m). X 4800.

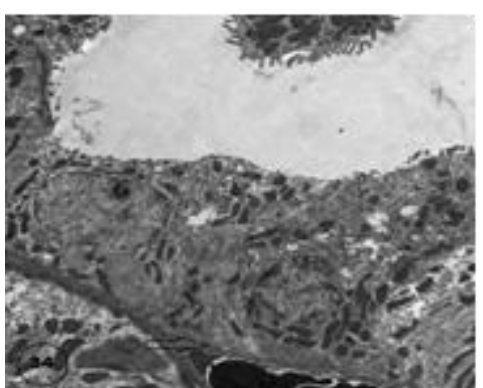

(Fig.34): Electron micrograph of the distal convoluted tubule of group VII rats showing well developed basal infolding (arrow) but still there are electron dense mitochondria (m). X4800.

\section{Discussion}

Carbon tetrachloride $\left(\mathrm{CCl}_{4}\right)$ is a potent nephrotoxic chemical. The target of $\mathrm{CCl}_{4}$ is the brush borderbearing proximal tubule cells (Kang et al., 2011). Oxidative stress damage by generation of free radicals is implicated in the pathogenesis of kidney injury (Hismiogullari et al., 2015).

The metabolic conversion of $\mathrm{CCl}_{4}$ by cytochrome $\mathrm{P}-450$ give rise to formation of the reactive metabolite trichloromethyl radical $\left(\mathrm{CCl}_{3}\right)$ and trichloromethyl peroxide radical $\left(\mathrm{CCl}_{3} \mathrm{O}_{2}\right)$. When the $\mathrm{O}_{2}$ tension rises, a greater fraction of $\mathrm{CCl}_{3}$ present in the system reacts very rapidly with $\mathrm{O}_{2}$ and more reactive free radicals, such as $\mathrm{CCl}_{3} \mathrm{O}_{2}$ is generated. The free radicals initiate the peroxidation of membrane poly unsaturated fatty acids, cell necrosis, GSH depletion, membrane damage and loss of antioxidant enzyme activity (Ganie et al., 2011).

Carbon tetrachloride $\left(\mathrm{CCl}_{4}\right)$ has been used in rat experimental models to investigate the oxidative stress induced in various organs (Haghi et al., 2014).

Exposure to $\mathrm{CCl}_{4}$ is commonly associated with acute and chronic renal damage (Mann et al., 2006) so this study aimed to investigate effect of $\mathrm{CCl}_{4}$ on the kidney by biochemical, histological and immunohistochemical investigations.

Male rats were used in this work because they were particularly suitable animal model for evaluating tubular lesions because their intrarenal enzyme distribution is similar to that present in man (WeichertJacobsen et al., 1999).

In this work $\mathrm{CCl}_{4}$ induced kidney damage which evidenced by biochemical assays of renal function tests by presence of increase level of serum urea, creatinine and uric acid. Also elevated serum level of the oxidative stress markers; malondialdehyde and NO. In addition, reduced antioxidant enzyme activity in kidney as shown by decrease level of GSH and SOD. Histopathological and immunohistochemical investigations confirmed occurrence of kidney damage. This was recorded by study of El-Gengaihi et al., (2013).

The present study was designed to evaluate the possible protective effect of captopril and nigella sativa oil against the $\mathrm{CCl}_{4}$ induced oxidative stress and nephrotoxicity by biochemical, histopathological and immunohisto-chemical

It was reported that captopril inhibits the conversion of angiotensin I into angiotensin II. The peptide angiotensin II (AngII) plays a prominent role in oxidative stress-related disorders through actions on the AngII- AT1 receptors. AngII, is a potent inducer of reactive oxygen species (ROS), oxidative stress and inflammation in many cells (Bernstein et al., 2013).

It was found that captopril has renoprotective effective. Thus, it could be useful in conditions associated nephrotoxicity such as hypertension with acute glomerulonephritis, acute and chronic renal failure (Rahman et al., 2009).

The sulphydryl-containing captopril appears to act as a scavenger of oxygen derived free radicals. Captopril decreased MDA concentration and activity of both glutathione reductase and peroxidase (Ackerman et al., 2008).

In this work the NO level as an oxidative stress marker was increased in $\mathrm{CCl}_{4}$ treated rats which was reported by Malekinejad et al. (2012), in addition to histopathological and immuno-histochemical changes. The NO level is decreased and reach near normal level in single or combined captopril and nigella sativa oil administration.

It was reported that the $\mathrm{CCl}_{4}$ induced upregulation of inducible nitric oxide synthase expression (Annadura et al., 2011). The NO level is corrected near normal by captopril. Also captopril can normalize renal morphological and functional alterations in rats. The protective effect of captopril is related to regulation of endothelial NO synthase expression and to a normalization of the oxidative stress parameters due to the inhibition of angiotensin II (García-Estañ et al., 2006).

In harmony with the present study the results of Anand et al., (2011) who reported that the expression of the iNOS gene appeared to be up-regulated in the liver and kidney samples of $\mathrm{CCl}_{4}$ exposed untreated rats, whereas in $\mathrm{CCl}_{4}$ exposed chrysin-treated rats, the mRNA transcript levels of iNOS approximated to normal levels. 
Also in agreement with the present work the results of EL Denshary et al., 2012) who reported that sider honey and/or Korean ginseng extract as an antioxidant resulted in a significant improvement in all evaluated kidney function tests and oxidative stress parameters which disturbed by $\mathrm{CCl}_{4}$ administration.

In agreement with results of the present study that was reported in other studies that captopril was used to suppress lipid perioxidation, oxidative stress and improve the antioxidant enzymes level (GSH and SOD) reaching values closer to normal and correct the hepatic damage induced by $\mathrm{CCl}_{4}$. This hepatoprotection could be attributed, at least in part, to the free radical scavenging properties of the drug (ElKatib and Mansour 2001, Tuncer et al., 2003 and Mansour et al., 2011). Also study of El-Sayed et al. (2008) reported that captopril has protective effect against cisplatin-induced nephrotoxicity in rats.

In this study the nigella sativa oil decrease the elevated renal function tests, TBARS and decrease the elevated NO level to reach normal value and correct histopathological alteration in kidneys.

In agreement, many studies mentioned that the nigella sativa seed extracts and oil or pure thymoquinone were found to suppress oxidative stress, improve antioxidant enzyme levels and correct renal damage which induced by many nephrotoxic agents such as cyslosporine (Uz et al., 2008), amakicin (Abdelaziz and Kandeel, 2011), cisplastin (Hadjzadeh et al., 2012) and garamycin (Saleem et al., 2012).

It was found that nigella sativa seed extracts and oil corrected biochemical and oxidative stress damages induced by $\mathrm{CCl}_{4}$ in the liver (Mansour et al., 2001 and Kanter et al., 2005) and the blood (Meral and Kanter 2003).

In agreement, the results of studies which reported that decrease the elevated NO production by $\mathrm{CCl}_{4}$ by many substances which has antioxidant properties as ghrelin (Cetin et al. 2010), Mushroom insoluble polysaccharides (Nada et al. 2012), yam peel extract (Yeh et al. 2013)

It was mentioned that nigella sativa seed and thymoquinone corrected the decreased level of antioxidant enzymes (El Sayed, 2011).

In harmony the other studies which reported antioxidant activity of some herbal extracts that have potential protective effects against $\mathrm{CCl}_{4}$ toxicity similar to nigella sativa such as terminalia arjuna (Manna et al., 2006), digera muricata (Khan et al., 2009), sonchus asper (Khan et al., 2010), podophyllum hexandrum (Ganie et al., 2011), punica granatum (Abdel Moneim and El-Khadragy, 2013), oxalis corniculata (Khan and Zehra, 2013). These studies revealed that these substances decreased the elevated serum urea, creatinine and uric acid levels, diminished the increased lipid peroxidation, corrected the altered NO level, enhancing the decreased antioxidant enzymes activities (such as SOD, GSH) and corrected the histopathological finding of kidney damage.

The key enzyme involving $\mathrm{CCl}_{4}$ induced nephrotoxicity is cytochrome $\mathrm{P} 450$, which is localized in the cortical tubule cells, and the increased lipid peroxidation is evident in the renal brush border. $\mathrm{CCl}_{4}$ also affects renal mitochondrial function including calcium flux across mitochondrial membranes (Natarajan et al., 2006).

It was found that nigella sativa oil has effect on cytochrome $\mathrm{P} 450$ which is involved in nephrotoxicity and hepatoxicity (Ibrahim et al., 2008)

In agreement that was reported by Hwang et al., (2013) who mentioned that $\mathrm{CCl}_{4}$ induced renal damage through differential regulation of the caspase3. Renal damage was manifested by rise of blood urea nitrogen and serum creatinine, histologically showed decreased diameter of the glomerulus, a lower number of capillaries, and a convoluted tubule in the kidney section. This damage was corrected by administration of gomisin A which has antioxidant properties.

In addition, the present study revealed presence of histopathological changes in the kidneys by light and electron microscopic examination such as degeneration of renal glomeruli, thickening of basal membrane of renal tubules, dense mitochondrial, cytoplasm and lysosymes damage. The immunohistochemical examination showed high immunolabelling for activated caspase- 3 in the kidney in $\mathrm{CCl}_{4}$ treated rats. The concomitant administration of captopril and nigella sativa oil with $\mathrm{CCl}_{4}$ resulted in improvement of all mentioned changes.

In agreement with the current work was the study of Taskin et al., (2014) who reported that captopril and other inhibitors of angiotensin-II were effective against acute adriamycin

induced nephrotoxicity via restoration of mitochondrial membrane potential, adenosine triphosphate (ATP) production and prevention of mitochondrial damage in vivo.

In harmony the results of Hermenean et al., (2013) who reported that $\mathrm{CCl}_{4}$ resulted in increase of MDA concentration and decrease in GSH and SOD levels. These were accompanied by glomerular and tubular degenerations, vascular congestion, necrosis. Ultrastructural examination showed proximal and distal tubular epithelial cells alterations including dense numerous lysosomes, altered mitochondria and basal enfolding dilatation. Pre-treatment with naringenin which has antioxidant effect resulted in return of the changed biochemical and histopathological parameters to normal.

$\mathrm{CCl}_{4}$-induced profound elevation of reactive oxygen species production which generated from oxidative stress, as evidenced by increased level of lipid peroxidation and depleted the level of total antioxidant enzymes. Also it induced activation of apoptotic related proteins including caspase-3 (Haghi et al., 2014).

It was found that $\mathrm{CCl}_{4}$ caused increase in kidney MDA levels and prominent histopathological kidneys damage. Glomerular and tubular degeneration, interstitial mononuclear cell infiltration and fibrosis, and vascular congestion in the peritubular blood vessels were observed in the renal cortex. These histopathological changes were disappeared in rats treated with $\mathrm{CCl}_{4}$ plus caffeic acid phenethyl ester due to its antioxidant effect (Ogeturk et al., 2005). 
In this work the concomitant administration of captopril and nigella oil with $\mathrm{CCl}_{4}$ resulted in improvement of histological and immunohistochemical changes in the kidneys which may attributed to decrease apoptosis.

It was reported sesamin, L-theanine and curcumin attenuated $\mathrm{CCl}_{4}$-induced apoptosis through marked inhibition of caspase-3 activities. This inhibition is attributed to the antioxidant activities of these compounds, modulation of apoptosis signaling pathway or inhibiting metabolic activation of $\mathrm{CCl}_{4}$ (Jiang et al., 2012, Ma et al., 2014-a and Hismiogullari et al. 2015).

\section{Conclusions and Recommendations}

Captopril and nigella sativa oil have protective effects against renal damage induced by $\mathrm{CCl}_{4}$. The renoprotective effect of captopril is related to its antioxidant effect because it contains sulfhydryl (-SH) group and inhibition of caspase-3 activity which involved in apoptosis pathway.

The renoprotective effect of nigella sativa oil is related to its cytoprotective and antioxidant actions, suppression of cytochrome p450 in renal cortex which results in metabolic conversion of $\mathrm{CCl}_{4}$ to toxic metabolites and its effect on caspase- 3 .

Both decrease the elevated NO level to reach near normal level and protect the mitochondrial from damage. Their combined administration gives more potent renoprotective effect than single drug administration which is of therapeutic value against nephrotoxicity.

\section{References}

Abdelaziz I and Kandeel M (2011): The protective effects of nigella sativa oil and allium sativum extract on amikacin-induced nephrotoxicity.7(6) : $697-703$.

Abbas G, Silveira MG and Lindor KD (2011): Hepatic fibrosis and the renin-angiotensin system. Am. J. Ther. Nov ; 18(6):e202-8.

Abdel Moneim AE and El-Khadragy MF (2013): The potential effects of pomegranate (Punica granatum) juice on carbon tetrachlorideinduced nephrotoxicity in rats. J. Physiol. Biochem. Sep; 69 (3): 359-70.

Abdel-Zaher AO, Abdel-Rahman MS and Elwasei FM (2011): Protective effect of Nigella sativa oil against tramadol-induced tolerance and dependence in mice: role of nitric oxide and oxidative stress. Neurotoxicology. Dec;32(6):725-33.

Ackerman Z, Oron-Herman M Rosenthal $\mathrm{T}$ et al. (2008): Effects of amlodipine, captopril and bezafibrate on oxidative milieu in rats with fatty liver. Dig. Dis. Sci., March, 53 (3):77784.

Ahmed AF, Mahmoud MF, Ouf MA et al. (2011): Aminoguanidine potentiates the hepatoprotective effect of silymarin in $\mathrm{CCl}_{4}$ treated rats. Ann. Hepatol. April-June, Vol. 10(2): 207-15.
Ali BH and Blunden G (2003): Pharmacological and toxicological properties of Nigella sativa. Phytother.Res.

Apr;17(4):299-305.

Anand KV, Anandhi R, Pakkiyaraj M, et al. (2011): Protective effect of chrysin on carbon tetrachloride $\left(\mathrm{CCl}_{4}\right)$-induced tissue injury in male Wistar rats. Toxicol. Ind. Health. Nov; 27 (10):923-33.

Annadurai T, Vigneshwari S, Thirukumaran R, et al. (2011): Acetyl-L-carnitine prevents carbon tetrachloride-induced oxidative stress in various tissues of Wistar rats. J. Physiol. Biochem. Dec; 67(4):519-30.

Bernstein KE, Ong FS, Blackwell WLB, et al. (2013): A Modern understanding of the traditional and non traditional biological functions of angiotensin-converting enzyme. Pharmacological Reviews.;65:1-46.

Bozzola J (2007): Conventional specimen preparation techniques for transmission electron microscopy of cultured cells.Methods Mol Biol.;369:1-18.

Cetin E, Kanbur M, Cetin N, et al. (2011): Hepatoprotective effect of ghrelin on carbon tetrachloride-induced acute liver injury in rats. Regul. Pept. Nov. 10;171(1-3):1-5.

Cerson FL (1990): Histotechnology. General, Immunohistochemical Staining Methods. American Society of Clinical Pathologist. pp.233-234. Chicago-USA.

Choi JH, Kim DW, Yun N, et al (2011): Protective effects of hyperoside against carbon tetrachloride-induced liver damage in mice. $\mathrm{J}$. Nat. Prod. May 27; 74 (5):1055-60

Coulombe J and Favreau L (1963): A new simple semimicro-method for colorimetric determination of urea. Clin.Chem., 9: 102108.

Dautzenberg M, Keilhoff G and Just A. (2011): Modulation of the myogenic response in renal blood flow autoregulation by NO depends on endothelial nitric oxide synthase (eNOS), but not neuronal or inducible NOS. J Physiol. Oct 1;589(Pt 19):4731-44

Durary RA and Wallington ENA (1980): Carleton's Histological Technique 4 th edition, Oxford Univ. Press, London New York, Toronto.

Ellman GL (1959):Tissue sulfhydryl groups. Arch Biochem Biophys. May; 82 (1):70-7.

El- Denshary ES, Al-Gahazali MA and Mannaa FA, et al. (2012): Dietary honey and ginseng protect against carbon tetrachloride-induced hepatonephrotoxicity in rats. Exp. Toxicol. Pathol.,64 (7-8), Nov: 753-60.

El- Gengaihi SE, Hassan EE and Hamed MA (2013): Chemical composition and biological evaluation of Physalis peruviana root as hepato-renal protective agent. J. Diet Suppl. Mar ; 10 (1):39-53.

El- Katib AS and Mansour MA (2001): Prior treatment with captopril attenuates carbon tetrachloride- 
induced liver injury in mice. Res. Commun. Mol. Pathol. Pharmacol.July-Agu,110(1-2):316.

Ellman GL (1959). Tissue sulfhydryl groups. Arch. Biochem. Biophys. 82 (1): 70-7.

El-Sayed el-SM, Abd-Ellah MF and Attia SM (2008): Protective effect of captopril against cisplatininduced nephrotoxicity in rats. Pak. J. Pharm. Sci. Jul;21(3):255-61.

El-Sayed WM (2011): Upregulation of chemoprotective enzymes and glutathione by Nigella sativa (black seed) and thymoquinone in $\mathrm{CCl}_{4}$-intoxicated rats. Int $\mathrm{J}$. Toxicol. Dec;30(6):707-14.

Ganie SA, Haq E, Hamid A et al. (2011): Carbon tetrachloride induced kidney and lung tissue damages and antioxidant activities of the aqueous rhizome extract of Podophyllum hexandrum. BMC Complement Altern Med. Feb; 28: 11-17.

García-Estañ J, Ortiz MC, O'Valle F, et al. (2006): Effects of angiotensin-converting-enzyme inhibitors in combination with diuretics on blood pressure and renal injury in nitric oxidedeficiency-induced hypertension in rats. Clin. Sci. (Lond). Feb;110(2):227-33

Green LC, Wagner DA, Glogowski J, et al. (1982): Analysis of nitrate, nitrite and $[15 \mathrm{~N}]$ in biological fluids. Ann. Biochem.; 126: 131138.

Griffith OW (1980): Determination of glutathione and glutathione disulphide using glutathione reductase and 2-phenyl-pyridine. Anal. Biochem., 106:207-212.

Hadjzadeh MA, Keshavarzi Z, Tabatabaee Yazdi SA, et al. (2012): Effect of alcoholic extract of Nigella sativa on cisplatin-induced toxicity in rat. Iran J Kidney Dis. Mar;6(2):99-104.

Haghi ME Dehghan G, Banihabib N, et al. (2014): Protective effects of Cornus mas fruit extract on carbon tetrachloride induced nephrotoxicity in rats. Indian J. Nephrol., 24:291-6.

Hermenean A, Ardelean A, Stan M, et al. (2013): Protective effects of naringenin on carbon tetrachloride-induced acute nephrotoxicity in mouse kidney. Chem. Biol. Interact. Sep 25; 205 (2):138-47.

Hismiogullari AA, Hismiogullari SE, Karaca O, et al. (2015): The protective effect of curcumin administration on carbon tetrachloride $\left(\mathrm{CCl}_{4}\right)$ induced nephrotoxicity in rats. Pharmacol Rep. Jun;67(3):410-6

Hrenák J, Arendášová K, Rajkovičová R, et al. (2013): Protective effect of captopril, olmesartan, melatonin and compound 21 on doxorubicininduced nephrotoxicity in rats. Physiol. Res. Dec 12; 62 Suppl. 1:S181-9.

Huang CF, Hsu CN, Chien SJ, et al. (2013): Aminoguanidine attenuates hypertension, whereas 7-nitroindazole exacerbates kidney damage in spontaneously hypertensive rats: the role of nitric oxide. Eur. J. Pharmacol. Jan 15;699 (1-3):233-40.
Hwang IS, Kim JE and Lee YJ (2013): Protective effects of gomisin A isolated from Schisandra chinensis against $\mathrm{CCl}(4)$-induced hepatic and renal injury. Int. J. Mol. Med. Apr;31(4):88898 .

Ibrahim ZS, Ishizuka M, Soliman M, et al. (2008): Protection by Nigella sativa against carbon tetrachloride-induced down regulation of hepatic cytochrome $\mathrm{P} 450$ isozymes in rats. Jpn J. Vet. Res. Nov;56(3):119-28.

Iqbal M, Sharma SD, Zadeh HR, et al. (1996): Glutathione metabolizing enzymes and oxidative stress in ferric nitrilotriacetate $(\mathrm{Fe}$ NTA) mediated hepatic injury. Redox Report;2:385-391.

Jiang W, Gao M, Sun S, et al. (2012): Protective effect of L-theanine on carbon tetrachloride-induced acute liver injury in mice. Biochem Biophys Res. Commun. Jun 1; 422(2):344-50.

Kalaf AA, Mekawy ME, Moawad MS, et al. (2006): Comparative study on the protective effect of some antioxidants against $\mathrm{CCl}_{4}$ hepain rats. Eg. J. Nat. Tox. Toxins; 6(1):59-82.

Kang KY, Kim JN, Chang IY, et al. (2011): Calretinin immunoreactivity in normal and carbon tetrachloride-induced nephrotoxic rats. Acta Histochem. Nov; 113(7):712-6.

Kanter M, Coskun O and Budancamanak M (2005) Hepato-protective effects of Nigella sativa $\mathrm{L}$ and Urtica dioica L on lipid peroxidation, antioxidant enzyme systems and liver enzymes in carbon tetrachloride-treated rats. World J. Gastroenterol. Nov 14; 11 (42):6684-8.

Khan MR, Rizvi W, Khan GN, et al. (2009): Carbon tetrachloride induced nephrotoxicity in rat: Protective role of Digera muricata. J. Ethnopharmacol, 122: 91-99.

Khan RA, Khan MR, Sahreen Set al. (2010): Prevention of $\mathrm{CCl}_{4}$-induced nephrotoxicity with Sonchus asper in rat. Food Chem. Toxicol. Aug-Sep;48(8-9) : 24 69-76.

Khan MR and Zehra H (2013): Amelioration of $\mathrm{CCl}_{4}$ induced nephro-toxicity by Oxalis corniculata in rat. Exp. Toxicol. Pathol. Mar;65(3):32734.

Kirkwood BR and Sterner JA (2003): Essential Medical Statistics, 2nd edition, Blackwell Science Inclusion, USA.

Kono Y (1978): Generation of superoxide radical during autoxidation of hydroxylamine and an assay for superoxide dismutase. Arch. Biochem. Biophys. Feb; 186(1):189-95.

Larsen K (1972): Creatinine assay by a reaction-kinetic principal. Clin. Chem. Acta, 41: 209-217

Lowry OH, Rosebrough NJ, Farr AL, et al. (1951): Protein measurement with the folin phenol reagent. J.Biol. Chem.193:265-275.

Ma JQ, Ding J, Zhang L, et al. (2014-a): Hepatoprotective properties of sesamin against 
$\mathrm{CCl}_{4}$ induced oxidative stress-mediated apoptosis in mice via JNK pathway. Food Chem. Toxicol. Feb; $64: 41-8$.

Ma JQ, Ding J, Xiao ZH, et al. (2014-b): Ursolic acid ameliorates carbon tetrachloride-induced oxidative DNA damage and inflammation in mouse kidney by inhibiting the STAT3 and $\mathrm{NF}-\kappa \mathrm{B}$ activities. Int. Immunopharmacol. Aug; 21 (2):389-95.

Malekinejad H, Rahmani F, Valivande-Azar S, et al. (2012): Long-term administration of Silymarin augments proinflammatory mediators in the hippocampus of rats: evidence for antioxidant and pro-oxidant effects. Hum Exp Toxicol. Sep; 31 (9) : 921-30.

Manna P, Sinha M and Sil PC (2006): Aqueous extract of Terminalia arjuna prevents carbon tetrachloride induced hepatic and renal disorders. BMC Complementary Altern. Med.Sep. 6:33-45.

Mansour MA, Ginawi OT, El-Hadiyah T, et al. (2001): Effects of volatile oil constituents of Nigella sativa on carbon tetrachloride-induced hepatotoxicity in mice: evidence for antioxidant effects of thymoquinone. Res Commun. Mol. Pathol. Pharmacol. ;110(34):239-51.

Mansour MA, Al- Ismaeel H, Al-Rikabi AC, et al. (2011): Comparison of angiotensin converting enzyme inhibitors and angiotensin II type 1 receptor blockade for the prevention of premalignant changes in the liver. Life Sci. Aug 1;89(5-6):188-94.

Meral I and Kanter M (2003): Effects of Nigella sativa L. and Urtica dioica L. on selected mineral status and hematological values in $\mathrm{CCl} 4-$ treated rats. Biol. Trace. Elem. Res. Winter; $96(1-3): 263-70$.

Nada SA, Omara EA, Abdel-Salam OM, et al. (2010): Mushroom insoluble polysaccharides prevent carbon tetra- chloride -induced hepatotoxicity in rat. Food Chem. Toxicol. Nov; 48 (11): 3184-8.

Natarajan SK, Basivireddy J, Ramachandran A, et al. (2006): Renal damage in experimentallyinduced cirrhosis in rats: Role of oxygen free radicals. Hepatology. Jun;43(6):1248-56.

$\mathrm{Ng}$ HY, Tain YL, Lee YT, et al. (2013): Renin angiotensin system blockade ameliorates lead nephropathy. Biochem Biophys. Res. Commun. Aug 23; 438 (2): 359-63.

Ogeturk M, Kus I, Colakoglu N, et al. (2005): Caffeic induced nephrotoxicity and protective effect of betaine in Sprague Dawley rats. $\mathbf{J}$. Ethnopharmacol. Feb 28; 97(2):273-80.

Ohkawa H, Ohishi N and Yagi K (1979): Assay for lipid peroxides in animal tissues by thiobarbituric acid reaction. Anal Biochem; 95:351-8.

Pal PB, Pal S, Manna P, et al. (2012): Traditional extract of Pithecellobium dulce fruits protects mice against $\mathrm{CCl}_{4}$ induced renal oxidative impairments and necrotic cell death. Pathophysiology. Apr; 19 (2): 101-14

Pirinççioğlu M, Kızıl G, Kızıl M, et al. (2012): Protective effect of Öküzgözü (Vitis vinifera L. cv.) grape juice against carbon tetrachloride induced oxidative stress in rats. Food Funct., 3, 668-73.

Rahman MH, Hossain MZ, Rahman MA, et al. (2009): Effect of captopril on gentamicin induced nephrotoxicity in rats. J. Dhaka Med. Coll.; 18(1): 3-7.

Raza M, Alghasham AA, Alorainy MS, et al. (2008): Potentiation of valproate-induced anticonvulsant response by nigella sativa Seed constituents: The role of GABA Receptors. Int. J. Health Sci (Qassim). Jan;2(1):15-25.

Saleem U, Ahmad B, Rehman K, et al. (2012): Nephroprotective effect of vitamin $\mathrm{C}$ and Nigella sativa oil on gentamicin associated nephrotoxicity in rabbits. Pak.J.Pharm.Sci.Oct;25(4):727-30.

Taskin E, Ozdogan K, Kunduz- Kindap E, et al. (2014): The restoration of kidney mitochondria function by inhibition of angiotensin-II production in rats with acute adriamycininduced nephrotoxicity. Ren Fail. May;36(4):606-12

Tojo A, Welch WJ, Bremer V, et al. (1997): Colocalization of demethylating enzymes and NOS and functional effects of methyl arginines in rat kidney. Kidney Int. Dec; 52 (6):1593-6.

Tuncer I, Ozbek H, Ugras S, et al. (2003): Antifibrogenic effects of captopril and candesartan cilexetil on the hepatic fibrosis development in rat. The effect of AT1-R blocker on the hepatic fibrosis. Exp. Toxicol. Pathol., 55 (23): 159-66.

Uz E, Bayrak O, Uz E, et al. (2008): Nigella sativa oil for prevention of chronic cyclosporine nephrotoxicity: an experimental mode. Am. J. Nephrol. ;28 (3):517-22.

Wang J, Zhang Q, Mei X, et al., (2014): Hydroxysafflor yellow A attenuates left ventricular remodeling after pressure overload-induced cardiac hypertrophy in rats. Pharm Biol. 2014 Jan; 52(1):31-5.

Weichert-Jacobsen KJ, Bannowski A, Küppers F, et al. (1999): Direct amifostine effect on renal tubule cells in rats. Cancer Res. Jul 15; 59 (14): 3451-3.

Whitehead TP, Bevan EA and Leonardi A (1991): Defects in diagnostic kits for determination of ureate in serum. Clin. Chem., 37(6): 879-81.

Yeh YH, Hsieh YL and Lee YT. (2013): Effects of yam peel extract against carbon tetrachlorideinduced hepato-toxicity in rats. J. Agric. Food Chem. Jul; 61 (30): 7387-96. 


\section{الملخص العربح)}

\section{التأثير الوقائي للكابتوبريل وزيت حبة البركة المضاد للتسمم الكلوي

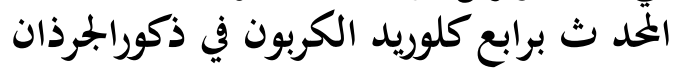 \\ خالا محمد عبد العال' ونشوى أحمد محمد مصطفى}

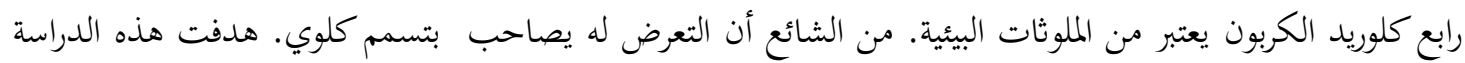

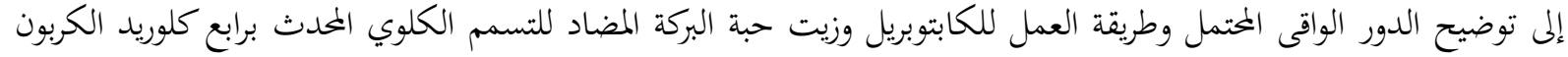

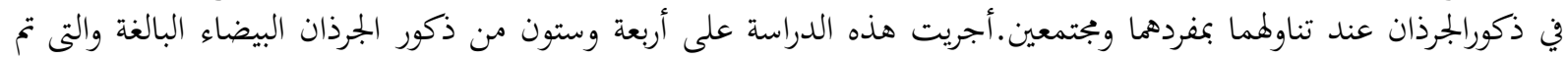

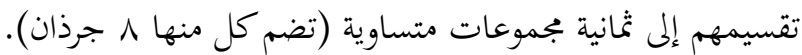
البجموعة الأولى هى جرذان المبلى المجموعة الضابطة السالبة.

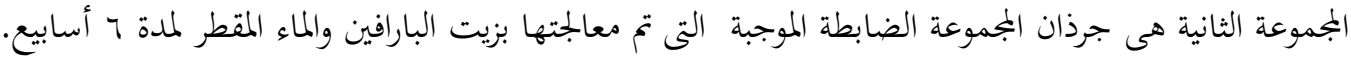

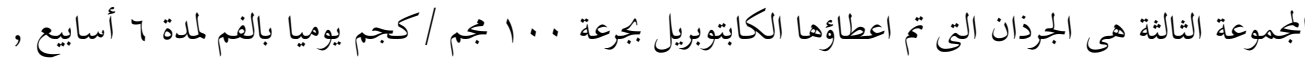

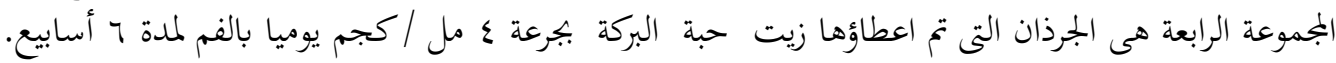

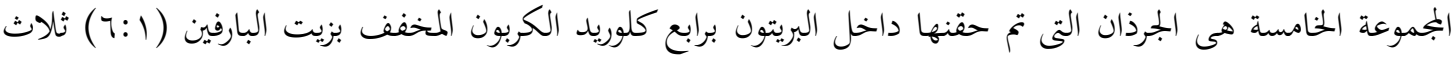

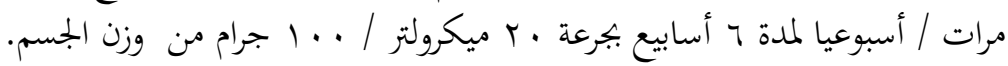

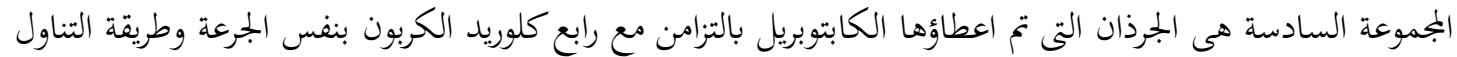
المذكورة سابقا لمدة 7 أسابيع. المجموعة السابعة هي الجرذان التى تم اعطاؤها زيت حبة البركة بالتزامن مع رابع كلوريد بنفس الجرعة وطريقة التناول المذكورة سابقا لمدة 7 أسابيع.

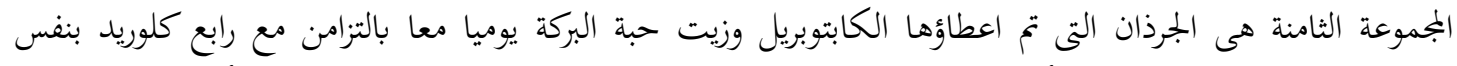

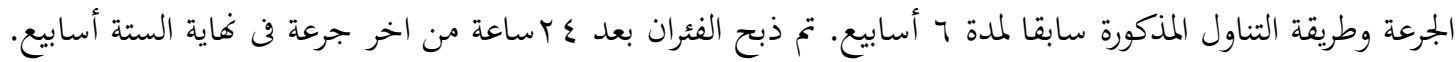

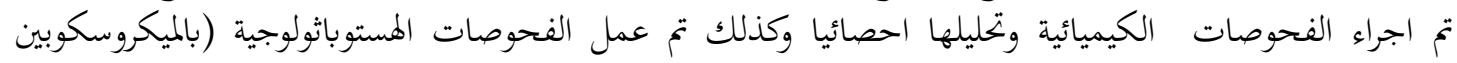

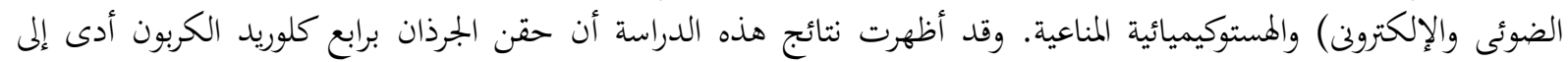

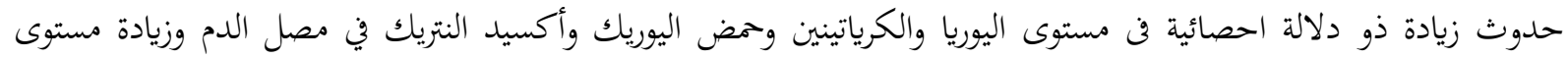

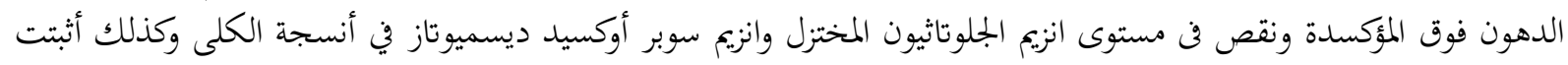

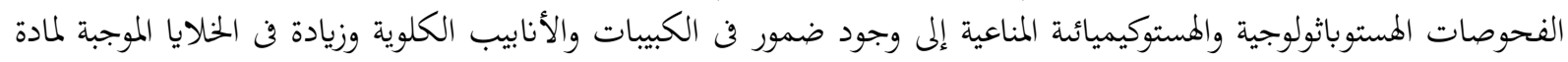

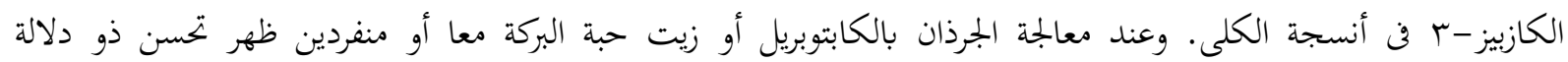

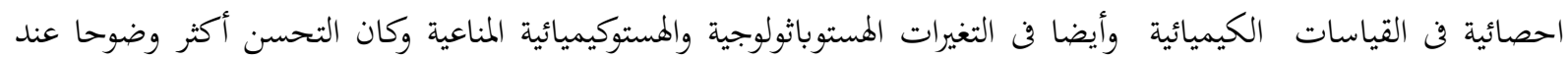

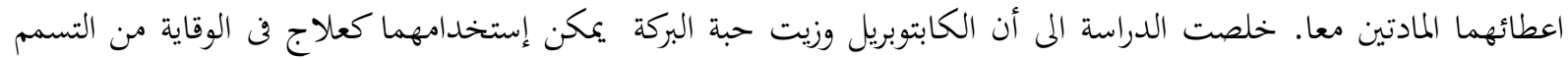

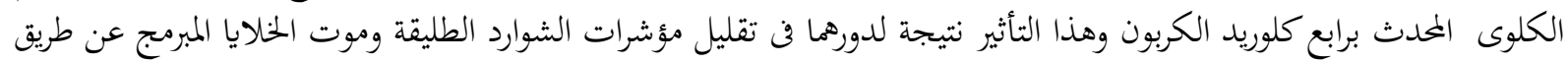

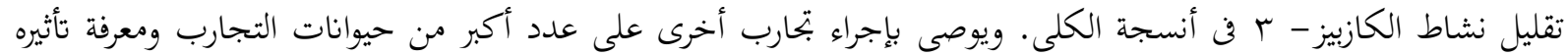

$$
\begin{aligned}
& \text { كعلاج في مرضى التسمم الكلوى. } \\
& \text { r قسم الهستولوجي - كلية الطب - جامعة أسيوط }
\end{aligned}
$$

